\title{
Notes on Cyclanthera brachystachya (Ser.) Cog.: Morphology, Ecology, and Its New Distribution
}

\author{
MUHAMMAD EFENDI ${ }^{1 *}$, RUGAYAH $^{2}$ \\ ${ }^{1}$ Cibodas Botanic Gardens - LIPI \\ Jl. Raya Kebun Raya Cibodas, Cianjur, West Java, Indonesia. 43253 \\ ${ }^{2}$ Herbarium Bogoriense, Botany Division, Research Center for Biology - LIPI \\ Jl. Raya Jakarta - Bogor Km. 46 Cibinong, Bogor, Indonesia. 16911. \\ *Email: muhammadefendi05@gmail.com
}

Received 11 October 2018; Received in revised form 10 December 2018;

Accepted 19 June 2019; Available online 30 June 2019

\begin{abstract}
Cyclanthera brachystachya (Cucurbitaceae) is an exotic species in Indonesia that originated from America. This species was reported running wild in several places in Java for decade ago. However, it is limited information to support this statement. This needs to be done, because $C$. brachystachya have potentially to increase the genetic resources of cucumber family in Indonesia. The methods used include morphological and ecological observation, including their distribution from their naturalized habitat in Indonesia. Morphology of this species were described based on living material from Cibodas Botanical Garden area. Morphologically, it is not different with other morphology description on flora of Java and other literatures. In their natural habitat, they grow on open areas with high humidity levels and variously substrate. This species spreads in the mountain of West Java, from Mt. Gede Pangrango to Mt. Manglayang Bandung and Garut. A new distribution in Sumatera added outside range of this species in their origin area in Indonesia.
\end{abstract}

Keywords: Cyclanthera explodens; Cibodas Botanical Garden, Cucurbitaceae; dragon cucumber; North Sumatera

\section{INTRODUCTION}

Cucurbitaceae is one of the largest family among Ordo Cucurbitales, there are about 120 genera, and 900 species, distributed all over the world. In Malesia, there are 37 genera, of which 29 native (de Wilde \& Duyfjes, 2010). This family characterized by an herbaceous plant, monoecious or dioecious with climbing or creeping, leaves simple, with tendril lateral to leaf (Xu \& Chang, 2017; Abdulrahaman et al., 2011; Fokou et al., 2009). The family is similar with Passifloraceae in its vegetative characters, but differs from Passifloraceae in its ovary position. About 12 genera, namely Benincasa, Citrullus, Cyclanthera, Cucurbita, Cucumis, Luffa, Sechium, Momordica, Sechium, Sicyos, Trichosanthes, Zehneria, well known used for fruits, vegetable, and medicinal purpose (Siemonsma \& Piluek, 1994; van Balgooy, 2001; de Wilde \& Duyfjes, 2010; VainioMattila, 2000; Lee et al., 2010).

Cyclanthera brachystachya (Ser.) Cog. (Syn. C. explodens Naudin), as a single species of Cyclanthera in Java, belongs to Cucumber family. It originated from Central America (de Wilde \& Duyfjes, 2010), and has been cultivated in Cibodas and other mountain forest of West Java (Backer \& Bakh. v/d Brink, 1963). However, there is no recorded of this in garden catalogue of Cibodas Botanical Garden (Teijsmann \& Binnendijks, 1866; Dakkus, 1930; Nasution, 1963), neither in van Steenis (1963). In addition, a limited specimens of Cyclanthera which were deposited in herbarium Bogoriense and Herbarium Cianjur Hortus Tjibodasensis. In this paper, we report and discuss some notes of morphology, ecology and distribution, as well as their utilization by local people in Cibodas.

\section{MATERIALS AND METHODS}

The study was conducted in Cibodas Botanical Garden area $( \pm 84.99$ ha). Samples were collected in the exploration that used free exploration method follow Rugayah et al. (2004). Data recorded includes number of individual plant, GPS position, and habitat. Observation the specimens also have been 
conducted in Herbarium Bogoriense (BO) and Herbarium Cianjur Hortus Tjibodasensis (CHTJ), to added the distribution record of $C$. brachystachya in Indonesia. Specimen identification refer to Backer and Bakh. v/d Brink (1963), de Wilde and Duyfjes (2010) and Singh et al. (2015).

\section{RESULT AND DISCUSSION}

Cyclanthera brachystachya (Ser.) Cogn. Diagn. Cucurb. (1877) (Figure 1).

Synonym. Cyclanthera explodens Naud. Ann. Sci. Nat. Bot. ser. 4(12): 160. 1859; C. explodens var. intermedia Cogn. ex Kuntze, Rev. Gen. P1. 3: 103. 1898; C. explodens var. trifida Cogn. ex Kuntze, Rev. Gen. Pl. 3: 103. 1898.

Local names. bobontengan, bonteng naga (Sund.), timun landak (Ind.), dragon cucumber (Eng.)

Morphology. Herbs, creeping and climbing to $5 \mathrm{~m}$. Stem green, tendril spiral, 1 or 2-branched, opposite with leaves. Leaves single, alternate, blade ovate, triangular, with 5-lobed up to half deep, acute in apex leaf, margine finely dentate. Male flower small, soliter or racemose, axilary, pedicles $1.0-5.0 \mathrm{~mm}$ length, tepal cup-like, 5-lobed, ca. $1 \mathrm{~mm}$. Female flower small size, soliter, with five tepal, ovary inferior. Fruit pepo type, green, obliquely ovoid-reniform, 3-8 cm length, fruit stalk $1-5 \mathrm{~cm}$, surface covered with trichomes horn-like, 3-5 mm length. Fleshy fruits 1.98-8.65 gr. weight, while its coat 1.887.95 gr. weight. Seed compressed, angular, narrowed five lobed, 5 to 11 seed each fruit, $10-14 \mathrm{~mm}$. length, $6.0-10 \mathrm{~mm}$ width and 40.85-96.65 gr. each1000 seeds in weight.

Germination and seedling. The germination type of this species is epigeal, which were begin germinating in 4 to 7 days after planting. The seeds coat will stay attached to the seedlings longer, at or slightly below the soil surface, its classified as cryptocotyle type.

Habitat The species mostly growing in open areas at 800 to $1.500 \mathrm{~m}$ asl, and in various substrat, including chalk-cliff, swamp and river bank.

Distribution. This species originated from Central America, throughout Africa and India, Malaysia, and Indonesia.

In Indonesia, its firstly reported in Cibodas (Backer \& Bakh. v/d Brink, 1963), but not known exactly the time when it was introduced to the place. Several years later, the species distribute to Mt. Manglayang Bandung and Garut District, West Java. Recently, an exploration teams of Herbarium Bogoriense (BO) as well as Cibodas Botanical Gardens, LIPI (2018) have collected the plant from Kabanjahe-Karo District to Piso-piso waterfall, North Sumatera.

Cyclanthera brachystachya belongs to an exotic species for some several areas in Asia and Africa, as reported by Singh et al. (2015) in India, and in Nigeria (Ajuru \& Nmom, 2017). Firstly, it's known only in cultivation, as vegetables for the upland tropic, at 1500 to $2000 \mathrm{~m}$ asl. (Jeffrey, 1980). Then, it has been naturalized in some part in Africa and Asia (Singh et al. 2015).

In Indonesia, it has been cultivated in Cibodas Botanical Garden for along year ago, then running wild from the gardens (Backer \& Bakh. v/d Brink 1963, de Wilde and Duyfjes 2010). Currently, they grow, spread and sustain self-replacing population (without direct intervention by people) in a new habitat. So, it can be classified into a naturalized species for Java according to Pysek et al. (2004).

In their natural habitat in Java, it grows in open area and can be found in vegetable plantation in around of Mt. Gede Pangrango National Park. It also wildly distributed in Mt. Manglayang Bandung to Garut, West Java. A new distribution of this species recently found in Brastagi, Kabanjahe District, North Sumatera added information of naturalized this species in Indonesia. Possibility, its introduced to North Sumatera by botanical garden activities, as also reported on Chimonobambusa quadringularis (Damayanto \& Muhaimin 2017) and Cobaea scandens (Efendi et al., 2019). 


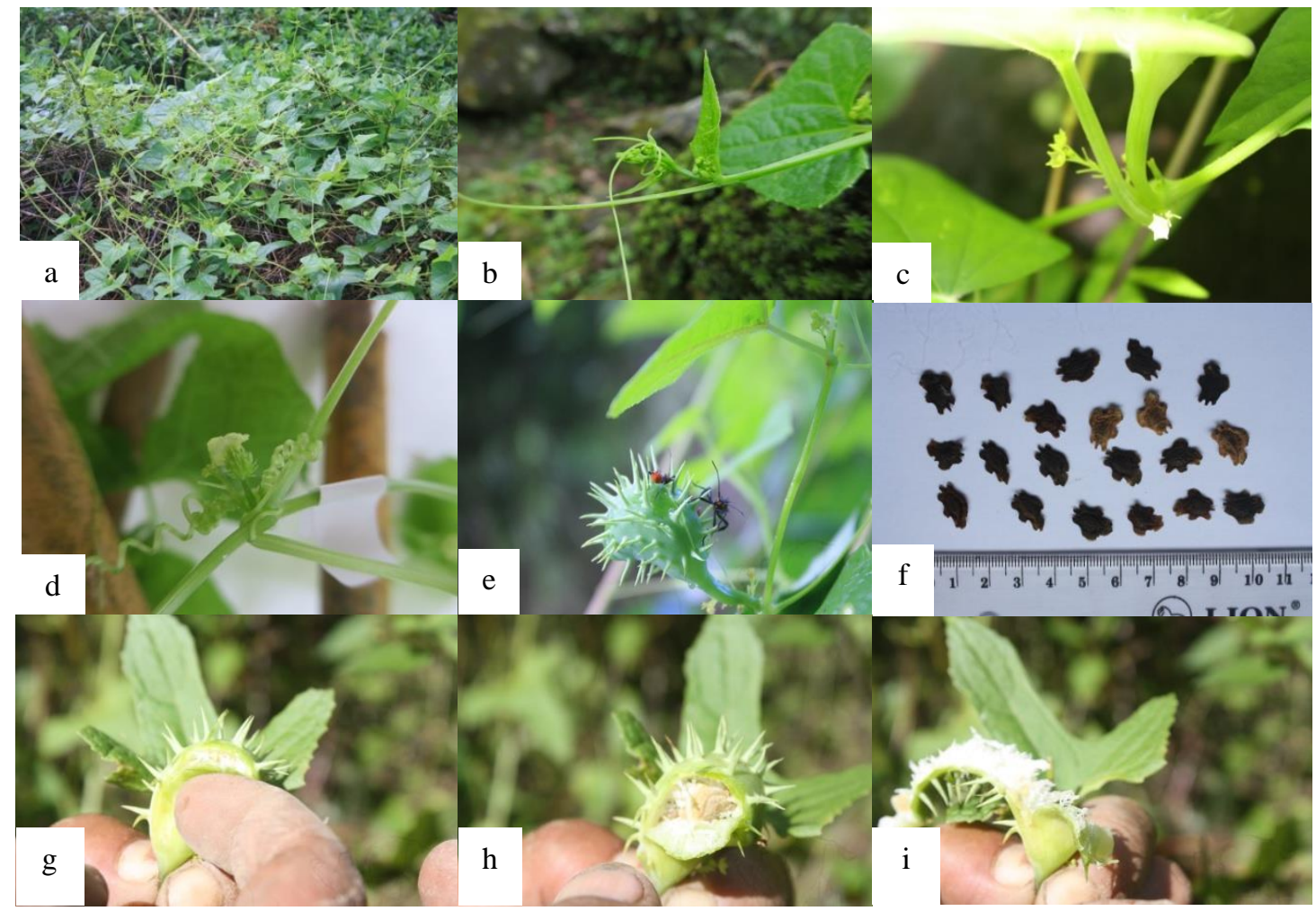

Figure 1. Cyclanthera brachystachya (Ser.) Cog. a. habit; b. shoot with axillary inflorescence; c. male flowers; d. female flower; e. fruit; f. seeds; g-i. seed dispersal process

Cyclanthera brachystachya well known as edible cucumber. Young fruit are eaten raw as fresh vegetable (Sund.: lalaban), while the young shoot and leaves are also used for vegetable, as like as in C. pedata that not found in Indonesia (de Wilde \& Duyfjes, 2010; Ajuru \& Nmom, 2017).

\section{CONCLUSION}

Cyclanthera brachystachya was originated species from America, then reported naturalized in Cibodas, to Manglayang and Garut. Some population were be found in Karo District, North Sumatera added a new distribution in Indonesia. In their natural habitat, they mostly growing in open areas at 800 to $1.500 \mathrm{~m}$ asl, and in various substrat. By local people, they used for vegetable and edible fruit.

\section{ACKNOWLEDGMENTS}

The authors would like to thank Mr. Endan from Cibodas Botanical Garden, who has helping for specimen collection in Cibodas.

\section{REFERENCES}

Abdulrahaman AA, Oyedotun RA, and Oladele FA. 2011. Diagnostic Significance of Leaf Epidermal Features in the Family Cucurbitaceae. Insight Botany. vol 1(2): 22-27. doi: 10.5567/BOTANYIK.2011.22.27.

Ajuru M and Nmom F. 2017. A review on the economic uses of species of Cucurbitaceae and their sustainability in Nigeria. $A J P B$. vol. $2(1)$ : 17-24. doi: 10.11648/j.ajpb.20170201.14.

Backer CA and Bakh. v/d Brink Jr. RC. 1963. Flora of Java (Spermatophytes only) vol I. Groningen, The Netherland: NVP Noordhoff. pp 306 - 307.

Dakkus PMW. 1930. An Alphabetical List of Plants Cultivated in Botanic Gardens, Buitenzorg. Bogor: Archipel Drukkerij Buitenzorg. p. 305.

Damayanto IPGP and Muhaimin M. 2017. Notes on Chimonobambusa quadrangularis (Franceschi) Makino (Poaceae: Bambusoideae) as an invasive alien plant species in Indonesia. Floribunda. vol. 5(7): 253-257. doi: 
http://dx.doi.org/10.32556/floribunda.v5i7 .2017.201.

de wilde JJO, and Duyfjes BEE. 2010. Flora Malesiana Seri - I: Seed Plant vol. 19. Cucurbitaceae. Bogor: Foundation Flora Malesiana. p. 333.

Efendi M, Muhaimin M., Suherman D. 2019. Sebaran populasi Cobaea scandens cav. sebagai tumbuhan invasif di Kebun Raya Cibodas dan sekitarnya. AL-KAUNIYAH: Journal of Biology. vol 12(1): 103-111. doi:

https://doi.org/10.15408/kauniyah.v12i1.9 033.

Fokou E, Achu MB, Kansci G, Ponka R, Fotso M, Tchiégang C, Tchouanguep FM . 2009. Chemical Properties of Some Cucurbitaceae Oils from Cameroon. Pakistan Journal of Nutrition. vol 8 (9): 1325-1334.

Jeffrey C. 1980. A review of the Cucurbitaceae. Bot. J. Linn. Soc. vol. 81: 233-247. doi: https://doi.org/10.1111/j.10958339.1980.tb01676.x.

Lee JM, Kubota C, Tsao SJ, Bie Z, Echevarria PH, Morra L, Oda M. 2010. Current status of vegetable grafting: Diffusion, grafting techniques, automation. Scientia Horticulturae. vol 127(2):93-105. doi: 10.1016/j.scienta.2010.08.003.

Nasution RE. 1963. An alphabetical list of plants species cultivated in the Hortus Botanicus Tjibodasensis. Bogor: Archipel. p. 65 .

Pysek P, Richardson DM, Rejmanek M, Webster GL, Williamson M, Kirschner J. 2004. Alien plants in checklists and floras: towards better communication between taxonomists and ecologists. Taxon. vol 53
(1):

135.

doi: https://doi.org/10.2307/4135498.

Rugayah, Retnowati A, Windadri FI, Hidayat A. 2004. Pengumpulan Data Taksonomi. In: Rugayah, Widjaja EA, Praptiwi (eds.). Pedoman Pengumpulan Data Keanekaragaman Flora. Bogor: Pusat Penelitian Biologi-LIPI. pp 5-42.

Siemonsma JS, Piluek K (eds.). 1994. Plant Resources of South East Asia. No. 8 Vegetables. Bogor: Prosea Foundation. p. 288.

Singh N, Singh B, Singh G, Thakur AK. 2015. Genus Cyclanthera Schrad. (Cucurbitaceae) in India with notes on distribution Cyclanthera brachystachya (Ser.) Cogn. in Himachal Pradesh, India. Phytodiversity. vol. 2(1): 51-55.

Teijsmann JE and Binnendijk S. 1866. Catalogus Plantarum: Horto botanico Bogoriensi. 'Slands Plantentuin Buitenzorg. Jakarta: Ter Lands-Drukkerij. p. 426.

Van Balgooy MMJ. 2001. Malesian Seed Plants. vol 3 - Potraits of Non-Tree Families. Leiden: National Herbarium Nederland - Universiteit Leiden Branch. pp. 257.

Vainio-Mattila K. 2000. Wild vegetables used by the Sambaa in the Usambara Mountains, NE Tanzania. In Annales Botanici Fennici. vol 37(1): 57-67. New York: Finnish Zoological and Botanical Publishing Board.

Xu Z, and Chang L. 2017. Cucurbitaceae. In: Identification and Control of Common Weeds: vol 3. Singapore: Springer. doi: https://doi.org/10.1007/978-981-10-54037_18. 